\title{
APSA Announces 2016 Small Research Grant Winners
}

W

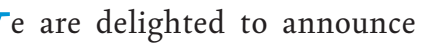
eleven recipients of the APSA Small Research Grants in 2016. Selected from over 50 applications through a competitive peer review process, the APSA Small Research Grant Program supports scholarship in all fields of political science and provides funding for research conducted by political scientists not employed at PhD-granting departments in the field, or who are in non-tenure track or contingent positions ineligible for departmental funding.

Prior grant recipients published books and book chapters, journal articles, working papers, and conference presentations as the result of the grants. They also report benefits to students, who have served as coauthors or research assistants on the grant-funded projects, and have reported public benefits in the form of briefings, consultancies with government or INGOs as a result of the research project funded. Several recipients have been able to use the APSA grant as seed money to gain additional funding.

\section{BURCU BAYRAM, UNIVERSITY OF TEXAS AT ARLINGTON AND ERIN GRAHAM, DREXEL UNIVERSITY}

Knowing How to Give: IO Funding Knowledge and Donor Publics' Preferences for Multilateral Foreign Aid

Conventional wisdom posits that citizens of donor countries prefer their governments to provide aid bilaterally rather than through international organizations. Our research inverts this view. We argue that publics' partiality toward bilateral aid is a function of lack of knowledge about how multilateral institutions are actually funded. Citizens are unaware that donor states can earmark their contributions and dictate how their money is used. We advance an information theory of public preferences for multilateral aid and hypothesize that when publics are informed about the opportunity to earmark funds, they will be more supportive of providing aid through multilateral organizations. To test our argument, we designed a new survey experiment that manipulates information about the opportunity to earmark. We requested funding to embed this experiment in YouGov Omnibus to obtain a nationally representative sample of 1,00o American adults. Our results will contribute to a fuller understanding of public preferences over foreign aid.

\section{BONNIE FIELD, BENTLEY \\ UNIVERSITY}

Women Ministers and Subcabinet Appointments in Parliamentary Democracies: The Case of Spain

The proposed project builds on the literature on women's political representation. It evaluates the recruitment hypothesis, which posits that having more women in political office, in turn, leads to additional women in office. Prior research has found a positive association between the presence of women in parliaments and cabinets, yet a negative association between women prime ministers and the nomination of women ministers. The latter finding suggests that women leaders may face very different incentives in making political appointments. Through a theoretically-informed, case study of Spain (1996-2015), I will evaluate whether this finding holds for subcabinet appointments, trace the underlying incentive structure that female ministers face when they make or seek to influence political appointments, and evaluate whether women subcabinet appointees follow similar career paths as their male counterparts, and, if so, if there is an effect of having served under a male or female minister.

\section{JEROME FOSS, SAINT VINCENT COLLEGE \\ Flannery O'Connor and Political Thought}

Many scholars have noted the theological subtext of Flannery O'Connor's stories, but her knowledge of the history of political philosophy often goes unnoticed. Without depreciating the important theological and religious themes of her work, I would like to focus on the political side of O'Connor's thinking. What impresses me about her stories is not just that she artfully captures scenes familiar to those living in modern America, especially the South, but that she also recognizes how our manners and habits are shaped by political ideas. She is familiar with Plato, St. Thomas Aquinas, Machiavelli, Descartes, Nietzsche, and many others.
I am currently engaged in writing a book that argues that Flannery O'Connor was incorporating and at times critiquing ideas from political theory in her fiction.

\section{GREG GOELZHAUSER, UTAH STATE UNIVERSITY}

\section{The Mechanics of Merit Selection}

Does merit selection favor better qualified and diverse applicants for judicial vacancies? Although proponents of merit selection argue that it should favor better qualified and diverse candidates, existing empirical studies indicate that merit selection systems do not produce better qualified or more diverse judges than other selection institutions. If merit selection is failing to sort on these candidates, however, it is unclear whether it is because they are not applying for consideration, nominating commissions are not forwarding them to the governor, or governors are not selecting them from commissionforwarded lists. To answer these questions, I am proposing the first research project that systematically examines decision-making within merit selection systems using information on applicants to particular judicialvacancies to be acquired through public records requests. This project will have important implications for our understanding of democratic performance and institutional design. It will also inform ongoing public policy debates concerning merit selection.

JENNIFER JACKMAN, SALEM STATE UNIVERSITY

Seals, Conflicts, and Public Policy: A Pilot Study of Voter, Angler, and Tourist Attitudes toward Seals on the Massachusetts Coast

This proposal sought funding to support research assistants and associated costs for a pilot study of attitudes on Nantucket towards seals, human-seal interactions, and related public policies. Surveys will be administered by mail to voters and on-site to anglers and tourists in June and July 2016. Nantucket is at the center of an intense political conflict between fishing interests and seals. The pilot study will enhance grant applications to fund a full-scale study of the views of voters, tourists, and fishermen at multiple locations along the Massachusetts coast in summer 2017. Both the pilot and the full-scale studies 
will help fill a research void on attitudes towards seals in the United States and public perceptions of the marine environment. This research will make important contributions to scholarship on problem definition and human dimensions of wildlife as well as current policy deliberations.

\section{HELEN KNOWLES, STATE UNIVERSITY OF NEW YORK OSWEGO}

The Real West Coast Hotel v. Parrish: A Case of Many Stories

The US Supreme Court's 1937 decision in West Coast Hotel v. Parrish, upholding a state minimum wage law for women, became famous for the wrong reason. Commentators labeled it "the switch in time that saved nine" because they believed that, when confronted with FDR's threat to reform the judiciary by packing the Court with liberal members, the justices reversed course and voted to uphold a law very similar to one struck down in 1936. Historians have shown the case was decided before FDR's announcement of his plan, yet Parrish continues to be viewed as a "landmark" decision because of the "switch." Consequently, scholars have generally ignored other reasons for Parrish's significance. Left unanalyzed are stories of the parties involved, and implications of Parrish for feminism, labor laws, and the framing of judicial decisions. The Real West Coast Hotel v. Parrish: A Case of Many Stories will fill this literary void.

\section{SUSAN LIEBELL, ST. JOSEPH'S UNIVERSITY}

Stand Your Ground: Guns, Rights, and Democratic Citizenship

Although issues of open carry and mass shootings occupy American policy and culture, the scholarly literature in political theory does not address what role gun rights play in political citizenship, economic fitness, or autonomous decision-making in a liberal democracy. Rejecting the freedom narrative of the NRA and many historians Stand Your Ground: Guns, Rights, and Democratic Citizenship argues that the right to keep and bear arms can only be understood if public claims (e.g., guns preserve the right to revolution) and private spheres (guns protect bodies and property) are separated. My book articulates six possible justifications for gun rights and critically assesses each-paying particular attention to how gender problematizes the logic and application of gun rights. Stand Your Ground laws represent a radical shift in the nature of liberalism-and they make no sense in the private sphere. This book provides a democratic theory of gun rights and regulation.

\section{JINEE LOKANEETA, DREW UNIVERSITY}

State Power and Legal Violence: Law, Policing, and the Truth Apparatus

In this book project, I theorize the nature of state power and legal violence in liberal democracies by focusing on the interaction of lawyers, police, and forensic psychologists in the use of three scientific techniques, namely lie detectors, brain scanning, and narcoanalysis (truth serums) in the criminal justice system. I explore the ways in which the study of these techniques enable insights into the workings of law, science, and policing, thereby leading to the theorization of state power based on a study of state and nonstate actors themselves. By interviewing police, lawyers, and forensic psychologists, and through an analysis of documents, cases, and videos, I argue that a study of these techniques enables a theorization of state and police power that is more contingent and constituted in its everyday practices as opposed to being monolithic thereby creating sites of specific critique and intervention and possible limits on legal violence.

\section{MONIQUE LYLE, UNIVERSITY OF SOUTH CAROLINA \\ An Expanded Examination of the Effects of Anti-Black Political Rhetoric on Self-Esteem}

This project will (1) replicate and expand a prior experiment examining how anti-black rhetoric attributed to political sources affects self-esteem among African Americans and whites and (2) pilot a study motivated by the aforementioned research that examines how political rhetoric legitimizing police officers' uses of force against African Americans affects self-esteem among African Americans and whites. The replicated experiment will (1) use a larger, more representative sample of African Americans and whites; (2) expand the design to include four additional treatment conditions; and ( 3 ) add additional follow-up questions to clarify the mechanisms through which anti-black rhetoric affects self-esteem. The new piloted study will be an experiment on the South Carolina State Survey ( $\mathrm{n}=800$ ) examining whether exposure to messages attributed to political sources legitimizing incidents of police officers' uses of force against African Americans affect self-esteem. A Small Research Grant from the American Political Science Association will be used to fund research assistantship for this project.

\section{RYAN SAYLOR, UNIVERSITY OF TULSA}

\section{A New Dataset on State Formation in Europe, 1600-1900}

Traditionally, the study of European state formation has relied on deep qualitative case studies. In recent years, economic historians have developed valuable time series data on per capita tax revenues, which has created new opportunities for scholarship on European state building. Yet these data series examine aggregate changes in taxation and do not specify key moments of institutional change, which were the hallmarks of state formation. This project will develop a new dataset, which will be made publicly available, on two momentous institutional changes in approximately a dozen countries. First, the dataset will identify when a country ended tax farming, which greatly enhanced extractive capacity. Second, the dataset will specify a critical two-step shift within some states: the emergence a proto-modern bureaucracy and the consolidation of a rational-legal state. A dataset on these institutional changes should be a boon to scholarship on European state formation.

\section{ZHIQUN ZHU, BUCKNELL UNIVERSITY}

\section{North Korea and East Asian Security}

This project studies the North Korea issue in the broad context of East Asian security and United States-China relations. The central thesis is that United States-China cooperation is key to resolving the North Korea problem. There is not so much a "North Korea problem" as a "United States-China problem." Using theories of asymmetric conflict and security dilemma in international relations, this project will trace North Korea's nuclear development as a national policy in response to its perceived international environment and examine how the nuclear issue has affected international security and Asian political economy. The instability at the heart of the nuclear-armed North Korea is a great threat to regional security. This policy-oriented research will also explore what the international community especially the United States, China, and South Korea can do to prepare for the eventual collapse of North Korea. 


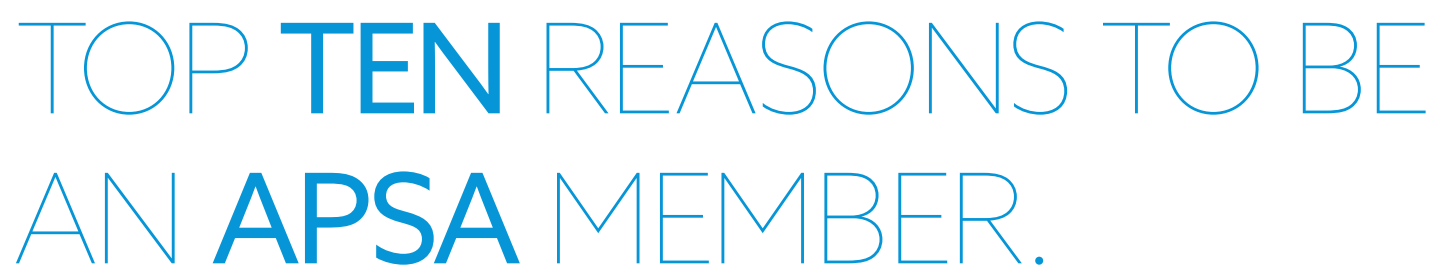

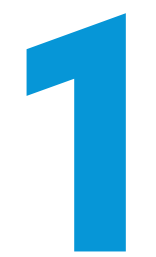

Increase your professional visibility \& stay connected to 12,000

political science professionals.

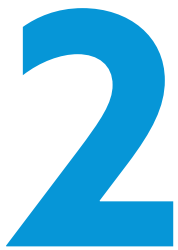

Stay up-to-date on the latest research in political science with access to APSA's three leading peer-reviewed political science journals.

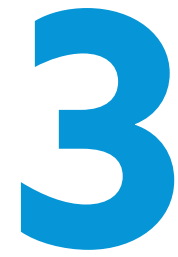

Search the latest job openings using APSA eJobs, the most comprehensive database of jobs related to political science. Browse the newest listings and upload your resume today!

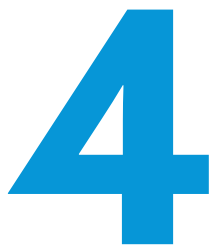

Engage with your colleagues interested in similar subfields of political science by joining an APSA Organized Section.

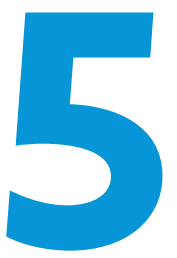

Enjoy member-only discounts of up to $46 \%$ off the registration fee for the APSA Annual Meeting and APSA Teaching \& Learning Conference.

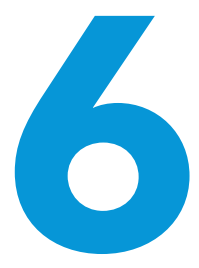

Get professional development advice \& support from experienced \& senior members of the profession through the APSA Mentoring Program.

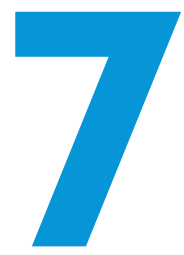

Get your research funded through one of the APSA Centennial Center's programs or by applying for a small research grant!

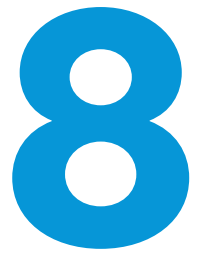

APSA recognizes excellence in the profession by awarding members for outstanding dissertations, papers, articles, \& books in various subfields of the discipline.

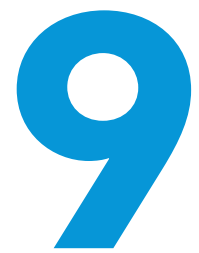

Apply for the Congressional Fellowship Program, a unique \& highly-selective non-partisan program devoted to expanding knowledge \& awareness of Congress.

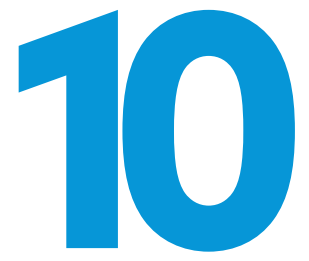

Get involved in one of APSA's International Programs designed to promote closer interaction between American and non-American political scientists. 


\section{apsa




\section{APSA Congressional Fellowship for Political Scientists}

\section{Apply now for the 2017-2018 fellowship year}

\section{Apply Now!}

Since 1953, the APSA Congressional Fellowship Program has brought more than 2,200 scholars and professionals to Washington, DC, to gain a hands-on understanding of Congress. Fellows begin their fellowship year with a comprehensive four-week orientation with leading congressional experts and policy leaders. Fellows then serve full-time placements of their choosing in the House of Representatives or Senate.

\section{The fellowship year also includes:}

- Winter and spring seminar series on Congress

- A trip to the district or state of a Member of Congress

- Optional study visits to Annapolis, Maryland, and Ottawa, Canada
QUALIFICATIONS: Applications are welcome from political scientists who have completed a PhD in the last 15 years or will have defended a dissertation in political science by November 2017. Candidates must be US citizens or permanent residents. The program is open to scholars in all subfields of political science who can show a scholarly interest in Congress and the policymaking process.

FELLOWSHIP YEAR: Orientation begins in November 2017. Office assignments run until August 15, 2018. Two optional programs precede the main fellowship year. Candidates may apply to take a course on Congress and Foreign Policy taught in September and October 2017, as well as apply for a fellowship through the William A. Steiger Fund to spend up to two months at the APSA Centennial Center carrying out a project in legislative studies.

STIPEND: $\$ 50,000$ for the 9.5-month fellowship period, plus a travel allowance.

SELECTION: Preference is given to those who have not had extensive Capitol Hill experience.

APPLICATION PROCEDURE: The application period opens in September 2016, and applications are due December 5, 2016. Applications must be submitted online and include:

- a detailed CV

- a 500-word personal statement explaining how the fellowship relates to professional goals

- the names and contact information for three professional references who have agreed to write letters of recommendation

- a writing sample

\section{Learn more at www.apsanet.org/cfp.}

